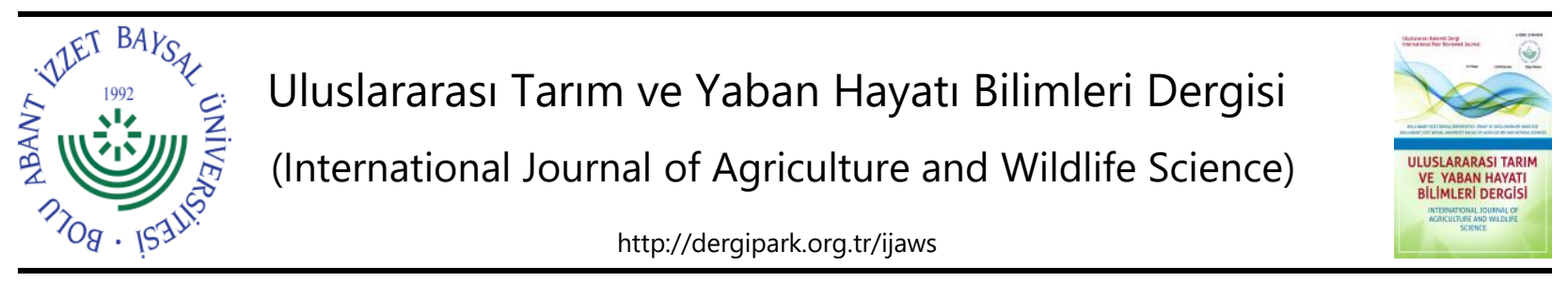

Araştırma Makalesi

\title{
Broyler Kümeslerinde Çalışan İş̧̧ilerin Amonyak Maruziyetlerinin Belirlenmesi
}

\author{
illker Kılıç
}

Bursa Uludağ Üniversitesi, Ziraat Fakültesi, Biyosistem Mühendisliği, Bursa

Geliş tarihi (Received): 14.05.2021

Kabul tarihi (Accepted): 06.07.2021

\begin{abstract}
Anahtar kelimeler:
Özet. Ucuz protein kaynağı olan tavuk eti üretimi konusunda ülkemiz dünyada önemli bir yere sahiptir. Bu Amonyak, broyler kümesi, iş sağlı̆̆ı, maruziyet nedenle üretim koşulları daha da iyileştirilerek üretim kalitesi ve miktarı artırılabilir. Benzer şekilde kümes iç ortam koşulları hem hayvan refahı hem de çalışan sağlığı ve güvenliği açısından iyileştirilmelidir. İş sağlığı ve güvenliği açısından tehlikeli işyeri olarak sınıflandırılan kümeslerde çalışan sağlığını etkileyen en önemli parametre kümes ortamında bulunan kirletici gazlar, partikül madde ve kokudur. Bu çalışmada Bursa bölgesinde faaliyet gösteren üç adet broyler kümesinde ölçülen amonyak $\left(\mathrm{NH}_{3}\right)$ konsantrasyonları iş̧̧i sağlığı ve güvenliği açısından maruziyet perspektifinde değerlendirmesi yapılmıştır. Bu amaçla çalışmada incelenen broyler kümeslerinde bir yıl boyunca kış ve yaz mevsimlerinde sürekli olarak 24 saat boyunca iç ortamda sıcaklık, bağıl nem ve hava hızı ile $\mathrm{NH}_{3}$ konsantrasyonları ölçülmüştür. Ölçümler sonucunda üç kümes içinde elde edilen kış mevsimi $\mathrm{NH}_{3}$ konsantrasyonları yönetmeliklerde belirtilen 8 saatlik maruziyet sınır değerlerini aştı̆̆ı görülmüştür. $\mathrm{NH}_{3}$ konsantrasyonları, bir günün, Broyler1 kümesinde $\% 100$ 'ünde, Broyler2 kümesinde \%34'ünde (8 saat) ve Broyler3 kümesinde \%87.5' inde (21 saat) kısa süreli maruziyet sınırı (20 ppm) üzerinde seyretmiştir. Özellikle Broyler1 kümesinde ölçüm saatlerinin bir kısmında 50 ppm'lik kısa süreli maruziyet sınıını bile geçmektedir. Buna karşın yaz mevsiminde ise her üç kümeste bile maruziyet sınır değerlerinin çok altında konsantrasyon değerleri elde edilmiştir. Sonuç olarak özellikle kış mevsiminde broyler kümesi iç ortamında bulunan $\mathrm{NH}_{3}$ konsantrasyonlarının azaltılması gerekmektedir. Azaltma yöntemleri arasında kirletici gazı daha oluşmadan kaynağında engelleyen kaynakta önleme stratejilerinin uygulanması en etkili yol olacaktır.

*Sorumlu yazar

ikilic@uludag.edu.tr
\end{abstract}

\section{Determination of Ammonia Exposures of Workers Working in Broiler Houses}

\section{Keywords:}

Ammonia, broiler house, occupational health, exposure

\begin{abstract}
Turkey has an essential role in the production of poultry, which is a cheap protein source. For this reason, the production quality and quantity can be increased by further improving the production conditions. Similarly, the indoor conditions of the poultry house should be improved in terms of both animal welfare and employee health and safety. The most critical parameter affecting the health of the workers in the poultry houses, classified as dangerous workplaces in terms of occupational health and safety, are the polluting gases, particulate matter, and odor in the poultry environment. In this study, ammonia $\left(\mathrm{NH}_{3}\right)$ concentrations measured in three broiler clusters operating in the Bursa region were evaluated from the perspective of exposure in terms of worker health and safety. For this purpose, indoor temperature, relative humidity, air velocity, and $\mathrm{NH}_{3}$ concentrations were measured continuously for 24 hours in winter and summer seasons in the broiler houses examined in the study. As a result of the measurements, it was observed that the winter season $\mathrm{NH}_{3}$ concentrations obtained in the three poultry houses exceeded the 8hour exposure limit values specified in the regulations. $\mathrm{NH}_{3}$ concentrations remained above the short-term exposure limit (20 ppm) in $100 \%$ of the Broiler1 house, $34 \%(8$ hours) in the Broiler2 house, and $87.5 \%(21$ hours) in the Broiler3 house. Especially in the Broyler1 house, it exceeds the short-term exposure limit of 50 ppm in some measurement hours. On the other hand, in summer, concentration values far below the exposure limit values were obtained even in all three houses. As a result, $\mathrm{NH}_{3}$ concentrations in the broiler house interior environment should be reduced, especially in winter. Among the mitigation techniques, implementing prevention strategies at the source, which prevents the pollutant gas at its source before it is formed, will be the most effective.
\end{abstract}




\section{GíRiş}

Dünya genelinde kanatlı eti üretimi, protein başta olmak üzere yağ asitleri ve vitaminler gibi moleküller bakımından besleyici içeriği yüksek besin kaynağı eldesini ekonomik olarak sağlaması dolayısıyla tarım ve gıda sektöründe önemli bir üretim alanını oluşturmaktadır. Küresel bazdaki üretim değerleri incelendiğinde kanatlı etleri arasında ilk sırayı broiler etinin aldığı görülmektedir. Broyler yetiştiriciliği, diğer tarım sektörleri ile kıyaslandığında iş gücü oranı az, gelişmiş ve teknolojiye açık bir üretim sektörüdür (Çiftçi ve Azman, 2008; Tonbak ve ark., 2017). Yetiştiricilikte üretim süresinin kısa olması, düşük sermaye gereksinimi ve yemden yararlanma oranının yüksek olması, üretimde kar oranını arttırmaktadır (Tümer ve ark., 2018).

Broyler tavuk üretiminde dünyada 1960 'larda başlayan gelişmeler sayesinde yaşanan hızlı artış günümüzde artarak devam etmektedir. Ülkemiz, sektörde 1980 'li yıllarda yaşanan gelişmelerle ve son yıllarda kümeslerde yaşanan kapasite artışılla birlikte broyler üretiminde ilk 10 ülke içinde yer alarak üretim payını arttırmış olup ülkemizde broyler et üretimi modern tesislerde, uluslar arası standartlara uygun olarak gerçekleştirilmektedir (Keskin ve Demirbaş, 2012; Sarıca ve ark., 2020). FAO (2019) verilerine göre 2019 yılında Dünya genelindeki mevcut tavuk sayısının 25915318000 adet, ülkemizdeki mevcut tavuk sayısının ise 342567000 adet olduğu belirtilmektedir. Ülkemizde 2019 yılı ocak-aralık döneminde tavuk eti üretimi 2138451 tona, kesilen tavuk sayısı 1207088000 adede; 2020 yılı ocak-aralık döneminde ise tavuk eti üretimi 2136263 tona, kesilen tavuk sayısı 1 200707 000'e ulaşmıştır (TÜiK, 2021).

6331 sayılı İş Sağlığı ve Güvenliği Kanununun 9'uncu maddesi uyarınca oluşturulan İş Sağlığı ve Güvenliğine İlişkin İşyeri Tehlike Sınıfları Tebliği'nde tavuk, beç tavuğu vb. yetiştiriciliği, kuluçkahane faaliyetleri ve kümes hayvanlarından yumurta üretimi tehlikeli sınıfta yer almaktadır (Anonim, 2012).

Broyler kümesleri içerisinde biyolojik faaliyetler neticesinde tavuklardan, yem partiküllerinden, altlıktan ve gübreden kaynaklanan zararlı gazlar, kümes hayvanları ve çalışanlar üzerinde birçok olumsuz etki barındırmaktadır (Yazarel ve ark., 2020).

Ülkemizde etlik piliç üretiminde gıda güvenliğini sağlamak, hayvan hastalık ve zararlıları ile etkili bir mücadele gerçekleştirmek amaçıla 2018 yılında Tarım ve Orman Bakanlığı tarafından kurulan e-reçete ve ilaç takip sistemi, tavuk eti ve yumurta gibi gıdalarda kalıntı izleme ve antibiyotik kullanımının azaltılması bakımından önemli bir adım olarak görülmektedir (Cihangir, 2020).

Literatürde tavukçuluk sektöründe iş sağlığı ve güvenliği ile ilgili birçok çalışmanın yer aldığı görülmektedir. Hayvan barınağında çalışanlar 8 saatten fazla bir süre boyunca 20 ppm seviyesindeki konsantrasyona maruz kalırsa kan üre azotu hızlı bir şekilde artar (Schiffman ve ark., 2006). Amonyak gazının yoğun olduğu kümeslerde çalışanların gözlerinde yanma ve sulanma, hapşırma, öksürme burun tıkanıklığı ve tahriş gibi semptomların görüldüğü, işçilerin kış aylarında ciddi solunum problemleri yaşadığı belirtilmektedir (Yazarel ve ark., 2020).

Çoktu (2015) gerçekleştirdiği çalışmada Manisa ilinde üretim yapan bir piliç işleme ve değerlendirme tesisi iş sağlığı ve güvenliği açısından değerlendirilmiştir. Üretimde karşılaşılan çeşitli riskler belirlenmiş ve analiz edilmiştir. Üretim tesisinin son 1 yıllık revir kayıtlarına göre çalışanların \%27'sinin kas iskelet sistemi rahatsızlıkları yaşadıkları belirlenmiştir. Bunun dışında solunum sistemi rahatsılıkları, cilt hastalıkları, kesik, batma, kayma, düşme ve çarpışma gibi sağlık ve güvenlik risklerinin de yer aldığı görülmektedir.

Çakır ve Ocaktan (2017) bir beyaz et entegre üretim tesisindeki iş sağığı ve güvenliği uygulamaları ve çalışan sağlık sorunlarının belirlendiği çalışmada çalışanların \%30,5'inin çalışma süresince iş kazası geçirdiği, geçirilen iş kazalarının yaklaşık yarısının kesik, çizik, kayma, takılma, düşmeden kaynaklandığı saptanmıştır. Son bir yıl içerisinde, çalışanların \%50.3'ünün belinde, \%39.4'ünün boynunda, \%37.6'sının el/el bileğinde, \%37.5'inin omzunda ağrı oluştuğu bildirilmiştir. Tesis çalışanlarının \%97,6'sının iş sağlığı ve güvenliği konusunda eğitim aldığı belirtilmektedir. Çalışanların \%85.8'inin gürültülü ortam koşullarında çalıştığı ve büyük çoğunluğunun kişisel koruyucu donanım kullandığı saptanmıştır.

Naseem ve King (2018) kümes içinde meydana gelen amonyak emisyonunun iyi bir havalandırma sistemi kullanılarak azaltılabileceğini, bu sayede kümes hayvanları ve çalışanların sağlık koşullarının iyileştirilebileceğini belirtmektedir (Yazarel ve ark., 2020).

Williams ve ark. (2017) broyler kümesindeki solunabilir toz ve amonyak konsantrasyonlarını azaltmak için yağmurlama soğutma sisteminin etkinliğini değerlendirdikleri çalışmada sistemin emisyon azaltmadaki etkisinin çok düşük olduğu, iş̧̧ilerin toz ve amonyak maruziyetini etkili bir şekilde azaltmak için uygun maliyetli mühendislik uygulamalarının, idari ve çalışanların maruziyet kontrollerinin yapılması gerektiği belirtilmektedir.

Bu çalışmada broyler kümesleri iç ortamında var olan $\mathrm{NH}_{3}$ konsantrasyonlarının iş sağlığı ve güvenliği açısından maruziyet perspektifinde değerlendirmesi yapılmıştır. 


\section{MATERYAL VE METOT}

Çalışmada incelenen broyler işletmeleri Bursa bölgesinde faaliyet göstermektedir. İşletmede kullanılan kümes mekanik havalandırmalı olup uzun kenar boyunca yerleştirilen pencerelerde aydınlatmanın yanı sıra havalandırma için kullanılmaktadır. Tavuklar yerde altık üzerinde yetiştirilmekte ve altıı olarak çeltik kavuzu kullanılmaktadır. İşletmede çalışan işçiler aileleri ile birlikte kümeste çalışmaktadırlar.

Çalışmada broyler kümesleri bir yıl boyunca kış ve yaz mevsimlerinde sürekli ölçümlerle izlenmiştir. Kümes iç ortamında, sıcaklık, bağıl nem ve hava hızı değerleri ile $\mathrm{NH}_{3}$ konsantrasyonları ölçülmüştür. İç ortam iklim koşulları sıcak telli çok fonksiyonlu sıcaklık-nem-hava hızı ölçer ile gerçekleştirilmiştir (Testo 435-2, Testo GmbH, Almanya). Amonyak konsantrasyonları ise elektro-kimyasal sensörlü gaz analizörü ile gerçekleşmiştir (MultiRAE-Lite, RAE, $A B D)$. Ölçüm cihazları kümeslerin enine ve boyuna orta noktasına yerleştirilmiştir. Ölçümler üç broyler kümesinde eş zamanlı olarak gerçekleştirilmiştir. Çoklu gaz ölçerler çalışanların solunum hizaları olan yerden $1.5 \mathrm{~m}$ yüksekliğe asılmıştır. Böylece çalışanların solunum seviyelerindeki konsantrasyon değerleri belirlenmiştir.

Çalışmada elde edilen $\mathrm{NH}_{3}$ konsantrasyonlarına ilişkin veriler ülkemizde uygulanan Kimyasal Maddelerle Çalışmalarda Sağlık Ve Güvenlik Önlemleri Hakkında Yönetmeliği'nde verilen maruziyet sınır değerleri ile karşılaştııılarak kümesler içerisindeki durumun iş sağlığı ve güvenliği açısından ne durumda olduğu belirlenmiştir.

Çalışmada incelenen broyler kümeslerinde ölçülen $\mathrm{NH}_{3}$ konsantrasyonlarının arasındaki farklıkların önemlilikleri varyans analizi ile belirlenmiştir. Bu analiz için JMP 7.0 istatistik yazııımı kullanılarak General Lineer Model analizi yapılmıştır.

\section{BULGULAR VE TARTIŞMA}

\section{Broyler Kümeslerinin Yapısal Özellikleri}

Çalışmada incelenen broyler kümeslerine ilişkin genel özellikler Çizelge 1'de verilmiştir. Broyler kümeslerinin kapasiteleri 10000-24000 tavuk arasında değişmektedir. Çalışmadaki broyler kümesleri mekanik havalandırma sistemi ile havalandırımaktadır. Broyler1 işletmesi mekanik havalandırma sisteminde $150 \mathrm{~cm}$ çapında 4 adet fan kullanırken, Broyler2 işletmesi $120 \mathrm{~cm}$ çapında 5 adet ve Broyler3 işletmesi $200 \mathrm{~cm}$ çapında 2 adet havalandırma fanı kullanmaktadır. Broyler kümeslerinde iç ortam sıcaklığı $30^{\circ} \mathrm{C}$ 'nin üstüne çıktığında fanlar çalıştırılmaya başlanmaktadır. İncelenen broyler kümeslerinde gübre, altlık üzerinde toplanmakta ve her yetiştirme periyodunun (35-45 gün) sonunda temizlenmektedir.

Çizelge 1. Çalışmada incelenen hayvan barınaklarının genel özellikleri.

Table 1. General characteristics of monitored broiler houses.

\begin{tabular}{lllll}
\hline İşletme adı & Yetiştiricilik sistemi & Kapasite & Havalandırma sistemi & Gübre temizleme \\
\hline Bro1 & Yerde & 10000 & Mekanik & Altlık \\
Bro2 & Yerde & 12000 & Mekanik+doğal & Altlık \\
Bro3 & Yerde & 24000 & Mekanik & Altlık \\
\hline
\end{tabular}

İncelenen barınaklara ilişkin alan ve hacim gibi özellikleri Çizelge 2'de verilmiştir. Çizelge 2'den görülebileceği gibi, broyler kümeslerinde kümes genişliği, 8.6-14.4 m arasında değişmektedir. İncelenen kümeslerin uzunlukları ise broyler kümeslerinde 27.7-100 m, arasında değişim göstermektedir. Broyler kümeslerinin genişlik ve uzunluk ölçülerine göre bu kümeslerde uygulanan yerleşim sıklığı incelendiğinde Broyler1 ve Broyler3 için oldukça sık bir yerleşimin olduğu söylenebilir. Bu durum kümes içerisindeki temiz havanın hızla tükenmesine ve işçi sağlığı açısından sorunlara yol açabilecektir.

Çizelge 2. Çalışmada incelenen hayvan barınaklarının yapısal özellikleri.

Table 2. Structural characteristics of monitored broiler houses.

\begin{tabular}{llll}
\hline İşletme & Barınak alanı $\left(\mathbf{m}^{\mathbf{2}}\right)$ & Barınak hacmi $\left(\mathbf{m}^{\mathbf{3}}\right)$ & Yerleşim sıklığı (Tavuk x $\left.\mathbf{~}^{-\mathbf{2}}\right)$ \\
\hline Bro1 & 336 & 1714 & 30 \\
Bro2 & 1250 & 4875 & 10 \\
Bro3 & 399 & 2075 & 33 \\
\hline
\end{tabular}

\section{iç Ortam iklimsel Çevre Koşullart}

Kümeslerde kış ve yaz mevsimlerinde yapılan ölçümler sonucunda ortalama sıcaklık, bağıl nem ve hava hızı değerleri Broyler 1 için sırasıyla $22.00^{\circ} \mathrm{C}, \% 68.84,0.11 \mathrm{~m} \cdot \mathrm{s}^{-1}$, Broyler 2 için, $25.68^{\circ} \mathrm{C}, \% 65.73,0.57 \mathrm{~m} \cdot \mathrm{s}^{-1}$, Broyler 3 
için $17.12^{\circ} \mathrm{C}, 67.02$ ve $0.21 \mathrm{~m} . \mathrm{s}^{-1}$ olarak belirlenmiştir. Kümeste yapılan iç ortam iklimsel çevre koşulları ölçüm sonuçlarına göre her üç kümes için, maksimum değerler sıcaklık için öğlen 12:00-14:00 arasında, bağıl nem için gece 23:00-02:00 arasında ve hava hızı için öğlen 12:00-14:00 arasında gerçekleşmiştir. Minimum değerler ise, sıcaklık için gece 22:00-01:00 arasında, bağıl nem için öğlen 12:00-14:00 arasında, ve hava hızı için sabaha karşı 02:00-05:00 arasında elde edilmiştir. Kümesler arasında en yüksek sıcaklık değeri Broyler 2' de, bağıl nem değeri Broyler 1'de ve hava hızı değeri Broyler 2'de ortaya çıkmışır.

Broyler tavukları için optimum sıcaklık değerlerini Türkoğlu ve ark. (2018), $10^{\circ} \mathrm{C}-25^{\circ} \mathrm{C}$ arasında, Butcher ve ark. (2019) $21^{\circ} \mathrm{C}$ olarak bildirmektedirler. Optimum bağıl nem değerleri ise \%65-80 arasındadır (Olgun, 2016).

\section{Işs Sağlığı ve Güvenliği Açısından Amonyak Konsantrasyonları}

Çalışmada incelenen broyler kümeslerinde kış ve yaz döneminde ölçülen $\mathrm{NH}_{3}$ gazı konsantrasyonlarına ilişkin tanımlayıcı istatistikler Çizelge 3'de verilmiştir. Amonyak konsantrasyonlarının çalışma süresince 2-85 ppm, arasında değiştiği görülmektedir. Kümes iç ortamında yapılan ölçümler ile broyler işletmeleri için kış döneminde gerçekleşen ortalama $\mathrm{NH}_{3}$, konsantrasyonları en yüksekten düşüğe göre Broyler1, Broyler3 ve Broyler2 şeklinde sıralanmaktadır. Bu sıralama yaz döneminde ise Broyler3, Broyler1 ve Broyler2 olarak gerçekleşmiştir.

Çizelge 3. Broyler kümeslerinde ölçülen $\mathrm{NH}_{3}$ konsantrasyonları.

Table 3. $\mathrm{NH}_{3}$ concenrations measured in broiler houses.

\begin{tabular}{llll}
\hline \multirow{2}{*}{ Kümes } & Parametre & \multicolumn{2}{c}{$\mathbf{N H}_{\mathbf{3}}$ konsantasyonu(ppm) } \\
\cline { 3 - 4 } Bro1 & Ort & Kış & $4.43^{\mathrm{b}}$ \\
& Mak & $57.63^{\mathrm{a}}$ & 6.78 \\
& Min & 84.94 & 2.47 \\
& SS & 29.62 & 1.58 \\
Bro2 & Ort & 16.07 & $3.71^{\mathrm{c}}$ \\
& Mak & $17.31^{\mathrm{c}}$ & 4.80 \\
& Min & 25.73 & 2.88 \\
SS & Ort & 8.90 & 0.60 \\
& Mak & 4.38 & $6.20^{\mathrm{a}}$ \\
& Min & $26.77^{\mathrm{b}}$ & 7.77 \\
\hline
\end{tabular}

a-c Farklı harfler arasındaki farklılıklar istatistiksel açıdan önemlidir.

Çalışmada, broyler kümeslerinde maksimum gaz konsantrasyonları gece 01:00-05:00 arasında gerçekleşmiştir. Minimum değerler ise öğlen 11:00-14:00 arasında elde edilmiştir. Maksimum ve minimum $\mathrm{NH}_{3}$ konsantrasyonları sırasıyla kış döneminde Broyler1 ve Broyler2, yaz döneminde Broyler3 ve Broyler2 işletmesinde gözlenmiştir. Incelenen broyler kümeslerinde elde edilen $\mathrm{NH}_{3}$ konsantrasyonları arasındaki farklılıklar her ikisi mevsim için istatistiksel açıdan önemlidir $(P<0.05)$. Bu durum işletmelerde uygulanan bakım yönetim işlerinin farkıılaşmasının konsantrasyon üzerinde yarattığı farkııların önemli olduğunu göstermektedir.

Çizelge 4'de ülkemizde uygulanan Kimyasal Maddelerle Çalışmalarda Sağlık Ve Güvenlik Önlemleri Hakkında Yönetmeliği'nde $\mathrm{NH}_{3}$ gazı için verilen maruziyet sınır değerleri verilmiştir. Bu yönetmelik ayrıca Avrupa Birliğinde uygulanan 2009/161/EC numaralı yönetmeliğin paralelinde hazırlanmıştır. İş sağlığı ve güvenliği için çalışma ortamlarında $\mathrm{NH}_{3}$ konsantrasyonları çizelgede verilen değerleri geçmemelidir. Yönetmelikte iki farklı maruziyet sınır değeri belirlenmiştir. Bunlardan ilki bir günlük çalışma saati olan 8 saatlik sürede maruz kalınabilecek 8 saatlik maruziyet sınır değeri ve diğeri ise sadece 15 dakikalık bir sürede maruz kalınabilecek kısa süreli maruziyet sınır değeridir.

Çizelge 4. Kimyasal Maddelerle Çalışmalarda Sağlık ve Güvenlik Önlemleri Hakkında Yönetmeliğinde verilen mesleki maruziyet sınır değerleri.

Table 4. Exposure limits in Regulation on Health and Safety Measures in the Working of Chemicals.

\begin{tabular}{|c|c|c|c|c|}
\hline \multirow{2}{*}{ Kirletici gaz } & \multicolumn{2}{|c|}{8 saatlik maruziyet } & \multicolumn{2}{|c|}{ Kısa süreli maruziyet ( $15 \mathrm{dk}$ ) } \\
\hline & $\left(\mathbf{m g} \cdot \mathrm{m}^{-3}\right)$ & (ppm) & $\left(\mathbf{m g} \cdot \mathrm{m}^{-3}\right)$ & (ppm) \\
\hline $\mathrm{NH}_{3}$ & 14 & 20 & 36 & 50 \\
\hline
\end{tabular}



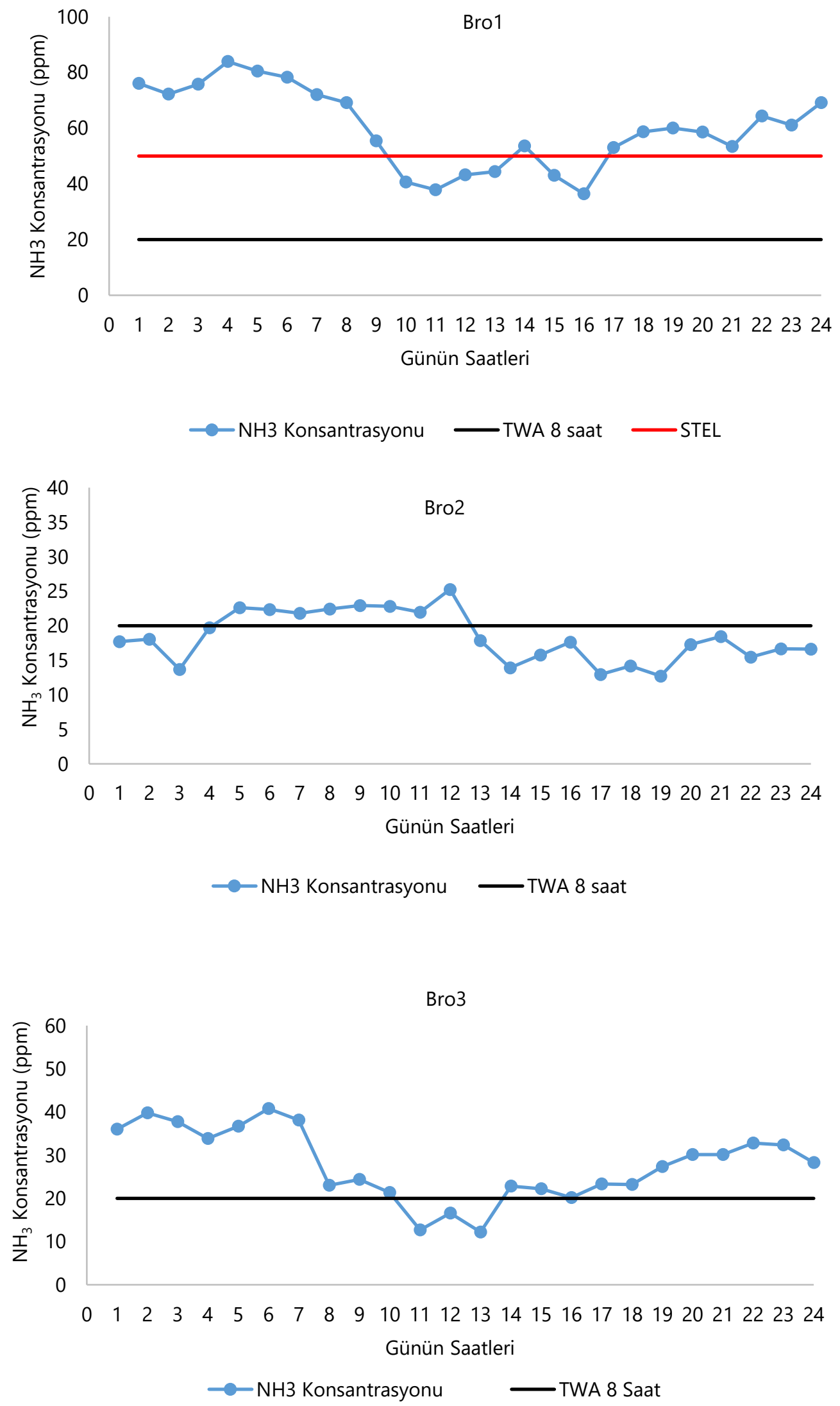

Şekil 1. İncelenen broyler işletmelerinde kış mevsiminde $\mathrm{NH}_{3}$ konsantrasyonunun saatlik değişimi. Figure 1. The hourly variation in $\mathrm{NH}_{3}$ concentrations in winter season in monitored broiler houses.

Şekil 1'de çalışmada incelenen broyler kümeslerinde kış mevsiminde elde edilen $\mathrm{NH}_{3}$ gazının günün saatlerine göre değişimi verilmiştir. Şekillerde yönetmelikte verilen maruziyet sınır değerleri kırmızı ve siyah çizgiler ile belirtilmiştir. Incelenen kümeslerden Broyler1 kümesinde kış mevsiminde havalandırmanın yetersiz olmasından dolayı $\mathrm{NH}_{3}$ konsantrasyonları yüksek değerlerde seyretmiştir. Bu nedenle elde edilen saatlik $\mathrm{NH}_{3}$ konsantrasyonu 
ortalamalarının tümünün 8 saatlik maruziyet sınır değeri (TWA 8 saat) olan 20 ppm'in üstünde gerçekleşmiştir. Elde edilen yüksek konsantrasyon değerleri 15 dakika maruz kalınması gereken kısa süreli maruziyet sınır değerlerini (STEL) bile aştığı şekil 1 de görülmektedir. Broyler1 işletmesinde sabah 10 öğleden sonra 16 saatleri arası hariç günün diğer saatlerinde $\mathrm{NH}_{3}$ konsantrasyonları kısa süreli maruziyet sınır değerini aşmaktadır. Broyler2 de sabaha karşı 5 ve öğle 12 saatleri arasında 8 saatlik maruziyet sınıının üstünde konsantrasyonlar gerçekleşmiştir. Broyler3 işletmesinde ise öğle 11 ve 13 saatleri arasında hariç olmak üzere günün tüm saatlerinde 20 ppm'in üstünde konsantrasyonlar ölçülmüştür. Yüksek konsantrasyon değerleri her üç kümes içinde sıcaklığın artmaya başladığı ve dolayısıyla havalandırmanın artış gösterdiği saatlerde azalma eğilimi göstermiştir. Genel olarak işçilerin kümes içerisinde aktif olarak çalıştıkları zaman dilimlerinde yüksek konsantrasyonlar elde edildiği söylenebilir. Bu durum iş sağlığı ve güvenliği açısından oldukça önemlidir ve üzerinde durulması gereken ciddi bir problem oluşturmaktadır.

$$
\square>20 \mathrm{ppm} \quad \square 50 \mathrm{ppm}
$$

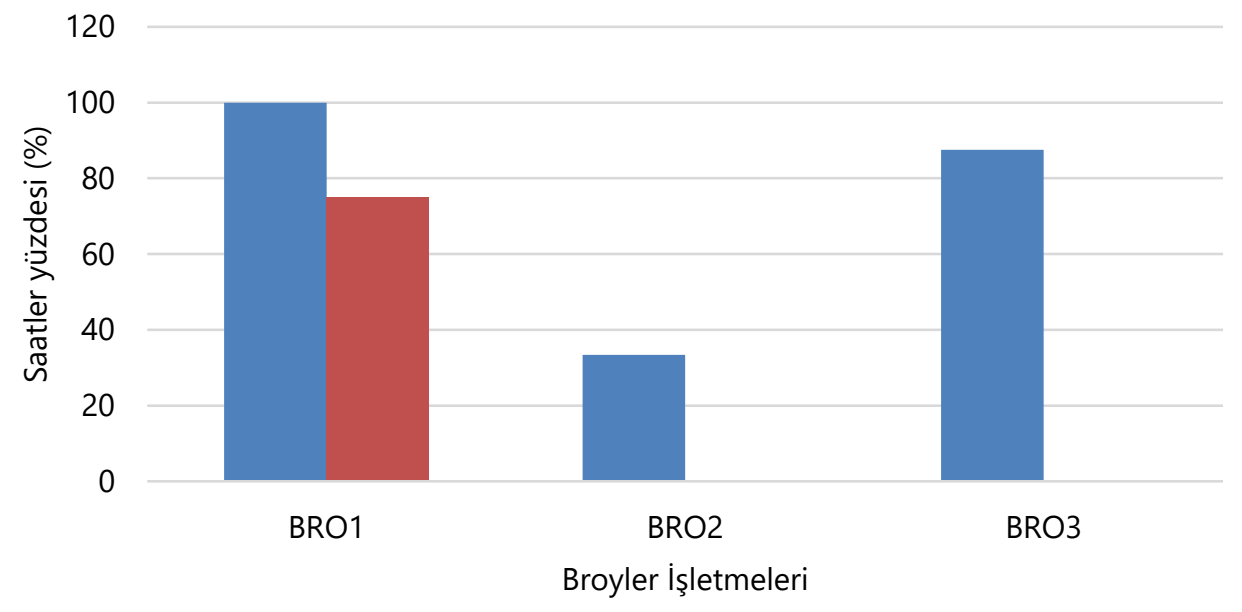

Şekil 2. Incelenen broyler kümeslerinde kış mevsimi $\mathrm{NH}_{3}$ konsantrasyonlarının maruziyet sınır değerlerini geçen saatler yüzdesi.

Figure 2. The percentage of hour exceeding exposure limits of winter $\mathrm{NH}_{3}$ concentrations in monitored broiler houses.

Çalışmada incelenen broyler işletmelerinde yaz mevsiminde ölçülen $\mathrm{NH}_{3}$ konsantrasyonları Şekil 3'de verilmiştir. Yaz döneminde elde edilen konsantrasyon değerleri yönetmelikte belirtilen 8 saatlik ve kısa süreli maruziyet sınır değerlerinin her ikisinin de altında gerçekleşmiştir. Çalışma sonucunda elde edilen veriler ışığında yaz mevsiminde kümeslerde gerçekleşen $\mathrm{NH}_{3}$ konsantrasyonlarının işçi sağlığı açısından tehlikeli boyutlara ulaşmadığı söylenebilir. Kümes iç ortam sıcaklı̆̆ının yaz mevsiminde optimum sınırlar içerisinde tutulabilmesi için havalandırma oranlarında gerçekleşen artışlar ve atlık materyalinin üzerine yeni altık eklenerek daha kuru tutulması kümes içerisindeki $\mathrm{NH}_{3}$ birikimini önlemekte ve böylece $\mathrm{NH}_{3}$ konsantrasyonlarının düşük değerlerde ölçülmesine neden olmaktadır.

Çalışmada elde edilen $\mathrm{NH}_{3}$ konsantrasyonları literatürde yapılan diğer çalışmalarla karşılaştırılmıştır. Broyler1 işletmesinde kış mevsiminde elde edilen ortalama $\mathrm{NH}_{3}$ değeri, 57.63 ppm ile önceki çalışmalara oranla daha yüksek gerçekleşirken, diğer broyler işletmelerinde ise elde edilen $\mathrm{NH}_{3}$ konsantrasyonları önceki çalışmalarla benzerlik göstermektedir. Broyler kümesleri iç ortamında $\mathrm{NH}_{3}$ konsantrasyonunu, Radon ve ark. (2002) 12.00 ppm, Redwine ve ark. (2002) 28.50 ppm, Liang ve ark. (2005) 37.00 ppm ve Kocaman ve ark. (2006) 23.06 ppm olarak bildirmişlerdir. 
Bro1
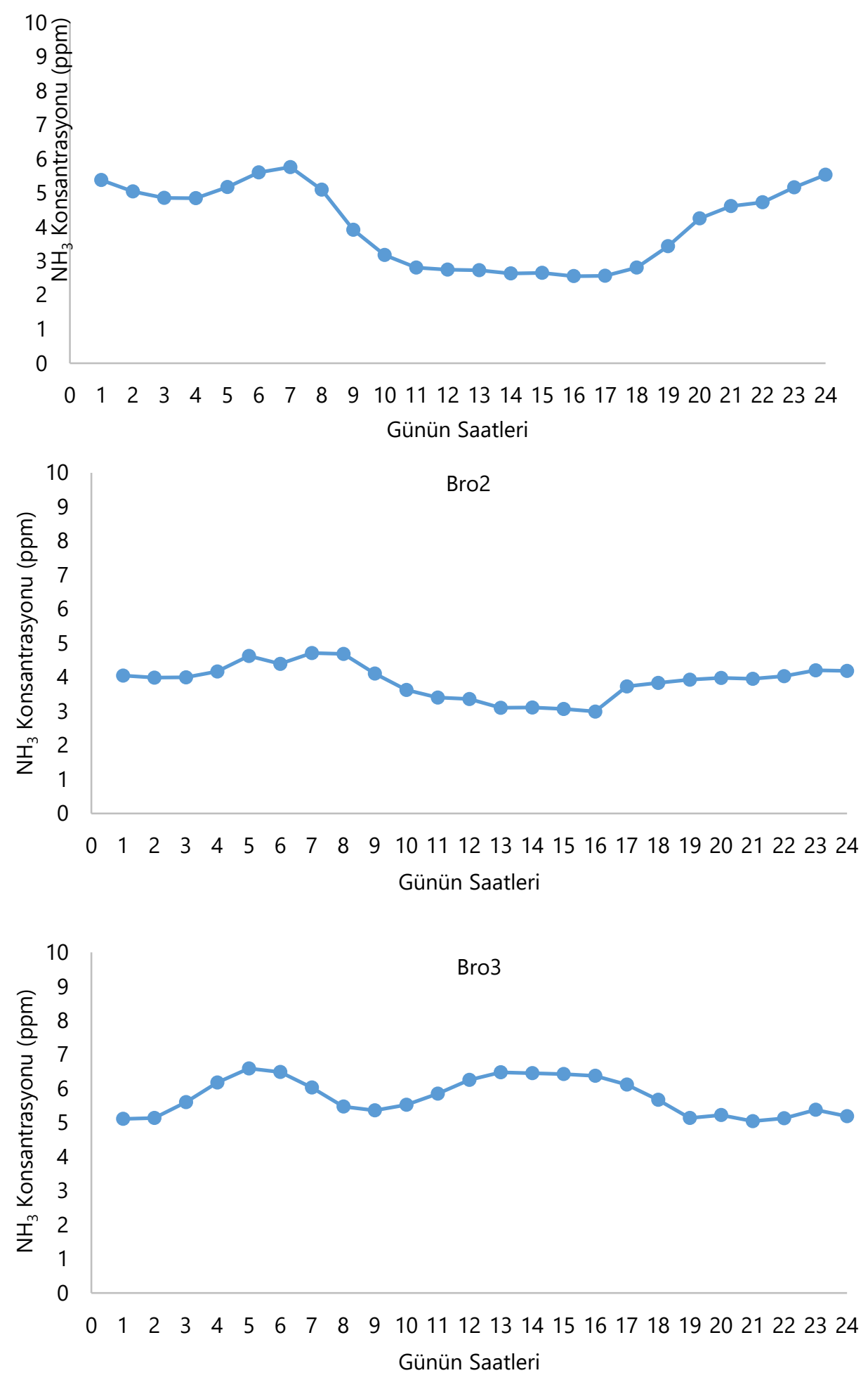

Şekil 3. İncelenen broyler işletmelerinde yaz mevsiminde ölçülen $\mathrm{NH}_{3}$ konsantrasyonunun saatlik değişimi. Figure 3. The hourly variation in $\mathrm{NH}_{3}$ concentrations in summer season in monitored broiler houses.

\section{SONUÇ}

Incelenen broyler kümesleri arasındaki $\mathrm{NH}_{3}$ konsantrasyonu arasındaki farklılıklar her iki mevsim içinde istatistiksel olarak önemlidir $(P<0.05)$.

Çalışma sonucunda broyler kümeslerinde kış mevsiminde ortaya çıkan $\mathrm{NH}_{3}$ konsantrasyonlarının iş sağlığı ve güvenliği ile ilgili yönetmeliklerde belirtilen 8 saatlik ve kısa süreli maruziyet sınır değerlerini aştığı belirlenmiştir. Özellik kış mevsiminde Broyler1 kümesinde elde edilen tüm verilerin 8 saatlik maruziyet sınır değerinin üzerinde olduğu ve hatta bazı değerlerin saatlerce kısa süreli maruziyet sınır değeri olan 50 ppm'in üzerinde seyrettiği 
gözlenmiştir. Bu konsantrasyon değerleri işçi sağlığı ve hayvan refahı açısından son derece tehlikelidir. Yaz mevsiminde ise çalışmada ele alınan tüm kümeslerde $\mathrm{NH}_{3}$ konsantrasyonlarının 8 saatlik maruziyet sınır değerinin altında seyrettiği belirlenmiştir. Bu sonucun oluşmasında bu mevsimde kümeslerde uygulanan altlık yönetimi ve havalandırma miktarlarındaki artış etkili olmuştur. Böylece broyler kümeslerinde çalışan iş̧̧iler için yaz mevsiminde kış mevsimine göre daha sağlıklı bir çalışma ortamının bulunduğu sonucuna ulaşılmıştır.

Incelenen kümeslerde uygulanan yerleşim sıklıkları değerlendirildiğinde en küçük yerleşim sıklığına sahip Broyler2 kümesinde kış ve yaz mevsimlerinde en küçük $\mathrm{NH}_{3}$ konsantrasyonlarının gerçekleştiği görülmüştür. Bu sonuç yerleşim sıklığının $\mathrm{NH}_{3}$ konsantrasyonu üzerinde etkileri olduğunu göstermektedir. Daha sık bir yerleşimde barınak içerisindeki temiz hava hızı bir şekilde tüketilmekte ve böylece aynı hızda kirletilmektedir. Uygulanan havalandırma miktarları kış mevsiminde iç ortam sıcaklığının düşmemesi adına aynı hızda artıılamadığı için içeride kirli hava birikmesi ve dolayısıyla $\mathrm{NH}_{3}$ konsantrasyonlarında artış yaşanmaktadır. Böylece yerleşim sıkığının hayvan refahının yanı sıra kümeslerde çalışan işçilerin sağlığı ve güvenliğini de etkilediği söylenebilir.

Çalışmanın yürütüldüğü kümeslerde işçilerin çalışma saatleri ve $\mathrm{NH}_{3}$ konsantrasyonları karşılaştırıldığında, kış mevsiminde işçilerin yoğun olarak çalıştıkları sabah 08:00 akşam 18:00 saatleri arasında özellikle sabah saatlerinde öğleden sonra saatlerine göre daha yüksek konsantrasyonların yaşandığı görülmüştür.

Çalışma sonucunda, broyler kümeslerinde kış mevsiminde gerçekleşen $\mathrm{NH}_{3}$ konsantrasyonlarının iş sağlığı ve güvenliği açısından son derece tehlikeli seviyelerde seyrettiği ve bu değerlerin yönetmelikte belirtilen maruziyet sınır değerlerinin altına indirilmesi gerektiği belirlenmiştir. $\mathrm{Bu}$ nedenle özellikle kış mevsiminde $\mathrm{NH}_{3}$ konsantrasyonlarının azaltılmasına yönelik olarak kümeslerde bir stratejinin uygulanması gerektiği açık bir sonuçtur. Azaltma yöntemleri arasında kirletici gazı daha oluşmadan kaynağında engelleyen, altlığa katkı maddesi ilavesi veya protein miktarı azaltılmış yem rasyonu gibi yöntemlerin uygulanması tavsiye edilir. Bu tip azaltma stratejilerinin uygulanması ile $\mathrm{NH}_{3}$ konsantrasyonları kabul edilebilir değerlere indirilebilir. Çalışma sonucunda önerilen her iki azaltma stratejisi için literatürde yapılmış birçok çalışma bulunmaktadır ve bu çalışmalarda önemli derecede yüksek arıtım verimliliği sonuçları elde edildiği görülmektedir. Angel ve ark. (2008), yumurta tavuklarında uygulanan standart yem rasyonundan \%0.5 oranında daha az protein içeren yem kullanarak amonyak konsantrasyonlarını \%39 oranında azaltılmıştır. Lora ve ark. (2008), Brezilya'da farklı yem rasyonlarının broyler performansı ve kirletici gaz salımları üzerine bir araştırma yürütmüşler ve çalışma sonunda \%17 oranında daha az amonyak ortaya çıkmıştır. Ritz ve ark. (2006), broyler kümeslerinde $\mathrm{NH}_{3}$ konsantrasyonlarını kontrol altında tutmak için demir II sülfat $\left(\mathrm{Fe}_{2}\left(\mathrm{SO}_{4}\right)_{3}\right)$ bileşiğini, kümesin her $93 \mathrm{~m}^{2}$ 'si için $45 \mathrm{~kg}$ uygulamışlardır. Çalışma sonunda, $\mathrm{NH}_{3}$ konsantrasyonlarındaki azalım oranları \%0-58 arasında değişmiştir. Burns ve ark. (2008), broyler kümeslerinde $\mathrm{NH}_{3}$ konsantrasyonları üzerine sıvı alümün altlık materyaline püskürtülmesinin etkisini araştırmışlardır. Çalışma sonuçlarına göre 41 günlük ölçüm süresince altlık materyaline düşük konsantrasyonlarda uygulanan SIVı alüm kümes içerisindeki $\mathrm{NH}_{3}$ konsantrasyonlarını \%90 oranında azaltmıştır.

\section{ÇIKAR ÇATIŞMASI}

Herhangi bir çıkar çatışması yoktur.

\section{YAZAR KATKISI}

IK; çalışmanın tasarlanması, verilen elde edilmesi ve değerlendirilmesi ile makale yazma işlemlerinin tümünü gerçekleştirmiştir.

\section{KAYNAKLAR}

Angel R., Powers W., \& Applegate T. (2008). Diet impacts for mitigating air emissions from poultry. Livestock Environment VIII, Iguassu Falls, Brazil.

Anonim. (2012). Işs sağlı̆ı ve güvenliğine ilişkin işyeri tehlike sınıfları tebliği, Resmi Gazete (26 Aralık 2012 tarihli), Sayı: 28509. BESD-BiR. (2021). istatistikler. https://besd-bir.org/tr/statistikler. Erişim tarihi: 10 Nisan 2021.

Burns, R., Moore, P., \& Moody, L. (2008). Using liquid aluminum sulfate to reduce poultry housing ammonia emissions. National Conference on Mitigating Air Emissions from Animal Feeding Operations, lowa State University, lowa,USA.

Butcher, G. D., \& Miles, R. (2019). Heat Stress Management in Broilers. Institute of Food and Agricultural Sciences, Cooperative Extension Service. University of Florida, Florida. 
Cihangir, F. (2020). Türkiye'de etlik piliç sektörünün ekonomik durumu ve sorunları. Yüksek Lisans Tezi, Bursa Uludağ Üniversitesi, Fen Bilimleri Enstitüsü, Bursa.

Çakır, M., \& Ocaktan, E. (2017). Işs sağlığı ve güvenliği yönünden beyaz et üretim sektörünün değerlendirilmesi. 4. Uluslararası Beyaz Et Kongresi, Antalya.

Çiftçi, M., \& Azman, M. A. (2008). Yumurtacı Tavukların Beslenmesi ve Etlik Piliçlerin (Broyler) Beslenmesi, Hayvan Besleme ve Beslenme Hastalıkları. Medipres Matbaacılık Yayınclık Ltd. Şti., Ankara.

FAO. (2021). http://www.fao.org/faostat/en/\#data/QA. Erişim tarihi: 9 Nisan 2021.

Keskin, B., \& Demirbaş, N. (2012). Türkiye'de kanatlı eti sektöründe ortaya çıkan gelişmeler: sorunlar ve öneriler. U.Ü. Ziraat Fakültesi Dergisi, 26, 117-130.

Lora, A., Rostagno, H. S., Albino, L. F. T., Lora, G., Lelis, G. R., \& Borsatto C. G. (2008). Nutritional strategies to reduce nutrient excretion in broilers. Livestock Environment VIII, Iguassu Falls, Brazil.

Naseem, S., \&, King, A. J. (2018). Ammonia production in poultry houses can affect health of humans, birds, and the environment-techniques for its reduction during poultry production. Environmental Science and Pollution Research, 25, 15269-15293.

Olgun, M. (2016). Tarımsal Yapılar. Ankara Üniversitesi Yayınları, Yayın No:1577, Ankara.

Ritz C. W., Harper L. A., Fairchild, B. D., Czarick, M., \& Pavlicek, J. (2006). Evaluation of ferric sulfate as a ammonia control product in commercial broiler production. Journal of Applied Poultry Research, 2006

Sarıca, M., Akkalkan, N., \& Erensoy, K. (2020). Traditional poultry production and commercial production opportunities in Kastamonu province. Journal of Poultry Research, 17(1), 35-40.

Schiffman S. S., Auvermann B. W., \& Bottcher R. W. (2006). Health Effects of Aerial Emissions from Animal Production Waste Management Systems, Animal Agriculture and the Environment, ASABE, Michigan, USA.

Tonbak, F., Atasever, M., \& Çalıcıoğlu, M. (2017). Kanatlı etlerinde salmonella riski. Atatürk Üniversitesi Veteriner Bilimleri Dergisi, 12, 90-98.

TÜiK. (2021). Kümes hayvancılığı üretimi. https://data.tuik.gov.tr/Bulten/Index?p=Kumes-Hayvanciligi-Uretimi-Aralik-202037214. Erişim tarihi: 9 Nisan 2021.

Tümer, E. İ., Ağır, H. B., \& Gürler, D. (2018). Broiler üretiminde üretici memnuniyetini etkileyen faktörler. Türk Tarım ve Doğa Bilimleri Dergisi, 5, 545-550.

Türkoğlu, M., Arda, R., Yetişir, M., Sarıca, M., \& Ersayın, C. (2018). Tavukçuluk Bilimi, Yetiştirme ve Hastalıkları. Otak From Ofset. Samsun.

Williams Ischer, S., Farnell, M. B., Tabler, G. T., Moreira, M., O'Shaughnessy, P. T., \& Nonnenmann, M. W. (2017). Evaluation of a sprinkler cooling system on inhalable dust and ammonia concentrations in broiler chicken production. Journal of Occupational and Environmental Hygiene, 14(1), 40-48.

Yazarel, S., Sarıca, Ş., \& Karaman, S. (2020). Mitigative practices for ammonia gas emissions from poultry manure. Turkish Journal of Agriculture - Food Science and Technology, 8, 111-115. 